\title{
Soybean Cyst Nematode Population Development and Associated Soybean Yields of Resistant and Susceptible Cultivars in Minnesota
}

\author{
S. Y. Chen, University of Minnesota Southern Research and Outreach Center, Waseca 56093; P. M. Porter and J. H. \\ Orf, Department of Agronomy and Plant Genetics, University of Minnesota, St. Paul 55108; C. D. Reese, University \\ of Minnesota Southern Research and Outreach Center, Waseca 56093; W. C. Stienstra and N. D. Young, Department \\ of Plant Pathology, University of Minnesota, St. Paul 55108; D. D. Walgenbach, University of Minnesota Southern \\ Research and Outreach Center, Waseca 56093; P. J. Schaus, Department of Agronomy and Plant Genetics, University \\ of Minnesota, St. Paul 55108; T. J. Arlt, University of Minnesota Extension Service-Steele County, Owatonna 55060; \\ and F. R. Breitenbach, University of Minnesota, Southeast District Extension Office, Rochester 55906
}

\begin{abstract}
Chen, S. Y., Porter, P. M., Orf, J. H., Reese, C. D., Stienstra, W. C., Young, N. D., Walgenbach, D. D., Schaus, P. J., Arlt, T. J., and Breitenbach, F. R. 2001. Soybean cyst nematode population development and associated soybean yields of resistant and susceptible cultivars in Minnesota. Plant Dis. 85:760-766.
\end{abstract}

The soybean cyst nematode (SCN), Heterodera glycines, is a major soybean yield-limiting factor, and the use of resistant cultivars is one of the most effective means to manage the nematode. During the past decade, a number of resistant cultivars in maturity groups I and II have been developed and made available to growers. A total of 47 resistant cultivars and nine susceptible cultivars were evaluated at 15 SCN-infested field sites and two noninfested sites during 1996 to 1998 in Minnesota. As expected, more nematodes developed on susceptible cultivars than on resistant cultivars. Egg density on susceptible cultivars increased by 1.9- to 10.6-fold during the growing season at 12 sites and did not change at the other three sites. Average egg density decreased over time for resistant cultivars at all sites, except where the initial egg density was low ( $\leq 455$ eggs per $100 \mathrm{~cm}^{3}$ soil). Nematode reproduction factors $(\mathrm{Rf}=$ egg density at harvest/egg density at planting) for individual resistant and susceptible cultivars were highly consistent across the eight sites where initial SCN density was more than 1,000 eggs per $100 \mathrm{~cm}^{3}$ soil. Resistance, however, varied among the cultivars, with the average $\mathrm{Rf}$ of individual resistant cultivars across the sites ranging from 0.3 to 1.7. Resistant cultivars produced an average yield of 3,082 kg/ha compared with 2,497 kg/ha by susceptible cultivars at eight of 10 sites where egg density at planting was greater than 700 eggs per 100 $\mathrm{cm}^{3}$ soil. In contrast, no difference in yield was observed between resistant and susceptible cultivars at sites where egg density at planting was lower than 500 eggs per $100 \mathrm{~cm}^{3}$ soil. Yield differences between resistant and susceptible cultivars increased with increasing initial SCN egg density. In six fields infested with initial densities of more than 5,000 eggs per $100 \mathrm{~cm}^{3}$ soil, resistant cultivars produced $28.4 \%$ (676 kg/ha) more yield on average than susceptible cultivars. Soybean yield increased when cultivars with increasing resistance to the SCN (lower Rf or females formed on roots) were grown in fields infested with SCN. Average relative yield (yield of a cultivar/average yield of all resistant cultivars at a site) of individual resistant cultivars across all $\mathrm{SCN}$-infested sites ranged from 0.76 to 1.10 . Yield consistency of soybean cultivars was low among the different sites, indicating that many other factors affected yield. Our results suggest growing resistant cultivars is an effective method to manage SCN in Minnesota while minimizing yield loss due to SCN.

The soybean cyst nematode (SCN), Heterodera glycines Ichinohe, has been found in most soybean (Glycine max (L.)

Corresponding author: S. Y. Chen

E-mail: chenx099@umn.edu

The research was supported by Minnesota Soybean Producers checkoff funding through the Minnesota Soybean Research and Promotion Council and Minnesota Agricultural Experiment Station.

Mention of any trade name or products does not imply endorsement of the products nor ignore other products either included in this study or not.

Accepted for publication 31 March 2001.

Publication no. D-2001-0507-01R

(C) 2001 The American Phytopathological Society have come from northern counties where soybean production is increasing.

The SCN has been managed effectively through use of resistant cultivars and crop rotation in the southern and central regions of the United States. A 2-year rotation with nonhost crops reduced SCN populations to below threshold damage levels in the southern United States $(5,15)$. However, in northern soybean production areas, the nematode survival rate may be higher, and a longer nonhost crop rotation may be needed. Research indicates that 3 years of corn did not reduce the nematode egg density from 7,000 to 14,000 eggs per $100 \mathrm{~cm}^{3}$ soil to below a damage threshold in Minnesota (S. Y. Chen, unpublished). Nematicides have been effective for the control of $\mathrm{SCN}$, but their use on soybean is not justified due to high costs and potential environmental damage $(10,16)$. The use of resistant cultivars is the most effective method to manage SCN. Growing the SCN-resistant cultivar Forrest in seven states in the southern United States prevented an estimated $\$ 401$ million in yield losses from 1975 to $1980(2,11)$.

In the past decade, SCN-resistant cultivars in maturity groups (MG) I and II have been developed, but reports on yield response of these resistant cultivars in fields are limited $(4,8,12,19)$. The objectives of this study were to determine yield responses of SCN-resistant and SCNsusceptible cultivars in MGI and MGII to $\mathrm{SCN}$, and to determine the SCN population development on these soybean cultivars in Minnesota fields.

\section{MATERIALS AND METHODS}

Cultivars and sites. A total of 56 cultivars were evaluated during 1996 to 1998. Most SCN-resistant cultivars in MGI and MGII currently available were included in this study. However, the number of cultivars varied among sites. Reaction to SCN, resistance sources, and maturity of the cultivars are described in Table 1.

A total of $15 \mathrm{SCN}$-infested and two noninfested field sites were located in six southern Minnesota counties during 1996 to 1998 . Soil texture, $\mathrm{pH}$, and organic matter level by site are summarized in Table 2 . Race of SCN in each infested site was 
determined following the general procedures described previously $(13,14)$ (Table $2)$. All sites were in an annual cornsoybean rotation except the 1996 Waseca (W96) and Lamberton (L96) sites, at which soybean had been grown continuously for 27 and 4 years, respectively.
Four replicates (four-row plots, $4.6 \mathrm{~m}$ long with 76-cm row spacing) of each cultivar were used at sites W96, L96, W97I, L97, W98I, W98III, L98I, L98II, G98, and K98, and three replicates (fourrow plots, $3.7 \mathrm{~m}$ long with $76-\mathrm{cm}$ row spacing) of each cultivar were used at sites
EC96, SJ96, NR96, W97II, SJ97, SJ98, and W98II (Table 2). Soybeans were grown at a rate of 395,000 seeds per hectare. In general, a conventional tillage regime of fall chisel plowing and spring field cultivation prior to sowing was used. Plots were cultivated in June, and various con-

Table 1. Average reproduction factor of Heterodera glycines (SCN), and SCN-resistance, maturity, and average yield of soybean cultivars in SCN-infested fields in Minnesota during 1996 to 1998

\begin{tabular}{|c|c|c|c|c|c|c|c|c|}
\hline \multirow[b]{2}{*}{ Cultivar } & \multirow[b]{2}{*}{ Company } & \multirow[b]{2}{*}{ Susceptibility ${ }^{\mathbf{a}}$} & \multirow{2}{*}{$\begin{array}{c}\text { Resistance } \\
\text { source }^{\mathrm{a}}\end{array}$} & \multirow[b]{2}{*}{ Maturity } & \multirow[b]{2}{*}{ Sites tested } & \multirow[b]{2}{*}{$\mathbf{R f}^{\mathbf{b}}$} & \multicolumn{2}{|c|}{ Average yield } \\
\hline & & & & & & & Relative yield $^{\mathrm{c}}$ & kg/ha \\
\hline 2069 & Asgrow & $\mathrm{R}$ & PI88788 & 2.0 & 6 & 1.2 & 1.04 & 3,037 \\
\hline 3171 & Thompson Seeds & $\mathrm{R}$ & Peking & 1.7 & 4 & 0.5 & 0.97 & 2,460 \\
\hline 9182 & Pioneer & $\mathrm{R}$ & PI88788 & 1.8 & 13 & 0.6 & 1.03 & 2,885 \\
\hline 9234 & Pioneer & $\mathrm{R}$ & Peking & 2.2 & 15 & 0.3 & 1.04 & 3,050 \\
\hline $1309 \mathrm{CN}$ & Croplan & $\mathrm{R}$ & PI88788 & 1.3 & 6 & 1.1 & 0.96 & 2,792 \\
\hline $1722 \mathrm{CN}$ & Croplan & $\mathrm{R}$ & PI88788 & 1.7 & 4 & 0.7 & 0.98 & 2,497 \\
\hline $1802 \mathrm{CN}$ & North Star & $\mathrm{R}$ & PI88788 & 1.8 & 8 & 0.9 & 1.02 & 3,008 \\
\hline $1882-1$ & Stine & $\mathrm{R}$ & PI88788 & 1.8 & 15 & 0.6 & 1.07 & 3,133 \\
\hline $2102 \mathrm{CN}$ & Croplan & $\mathrm{R}$ & PI88788 & 2.1 & 4 & 0.6 & 1.02 & 2,624 \\
\hline $2123 \mathrm{CN}$ & North Star & $\mathrm{R}$ & $\mathrm{ND}^{\mathrm{d}}$ & 2.1 & 2 & ND & 1.04 & 3,880 \\
\hline $2201 \mathrm{rr}$ & Asgrow & $\mathrm{R}$ & PI88788 & 2.2 & 6 & 0.9 & 1.05 & 3,080 \\
\hline $221 \mathrm{CN}$ & Prairie & $\mathrm{R}$ & PI88788 & 2.2 & 6 & 0.9 & 1.02 & 2,950 \\
\hline $2212 \mathrm{SCN}$ & Kruger & $\mathrm{R}$ & PI88788 & 2.0 & 6 & 0.9 & 1.00 & 2,960 \\
\hline $2220 \mathrm{SCN}$ & Kruger & $\mathrm{R}$ & PI88788 & 2.0 & 13 & 0.5 & 1.09 & 3,130 \\
\hline $2397 \mathrm{CN}$ & Ramy & $\mathrm{R}$ & ND & 2.3 & 2 & 0.7 & 1.03 & 3,849 \\
\hline 2444 SCN & Kruger & $\mathrm{R}$ & ND & 2.2 & 7 & 0.4 & 1.10 & 3,356 \\
\hline $2472 \mathrm{CN}$ & Stine & $\mathrm{R}$ & PI88788 & 2.3 & 2 & 0.3 & 1.03 & 3,086 \\
\hline $3216 \mathrm{CN}$ & Thompson Seeds & $\mathrm{R}$ & 88788/Peking & 2.1 & 6 & 0.8 & 1.05 & 3,070 \\
\hline $3219 \mathrm{CN}$ & Thompson Seeds & $\mathrm{R}$ & ND & 2.2 & 2 & ND & 1.05 & 3,919 \\
\hline $3236 \mathrm{CN}$ & Thompson Seeds & $\mathrm{R}$ & PI88788 & 2.2 & 6 & 0.6 & 1.06 & 3,157 \\
\hline $352 \mathrm{CN}$ & Latham & $\mathrm{R}$ & PI88788 & 1.9 & 7 & 0.4 & 1.00 & 2,933 \\
\hline $522 \mathrm{CN}$ & Latham & $\mathrm{R}$ & PI88788 & 2.1 & 15 & 0.5 & 0.95 & 2,793 \\
\hline 2540 & Asgrow & $\mathrm{R}$ & PI88788 & 2.5 & 2 & 0.5 & 1.00 & 2,972 \\
\hline Bell & IL Agric. Exp. St. & $\mathrm{R}$ & PI88788 & 1.9 & 15 & 0.5 & 0.96 & 2,804 \\
\hline BT216 CN & Ziller & $\mathrm{R}$ & PI88788 & ND & 9 & 0.5 & 0.97 & 2,597 \\
\hline CX-202 & Dekalb & $\mathrm{R}$ & PI88788 & 2.0 & 6 & 0.9 & 1.08 & 3,164 \\
\hline CX-160C & Dekalb & $\mathrm{R}$ & PI88788 & 1.6 & 6 & 0.7 & 1.02 & 3,003 \\
\hline CX-235C & Dekalb & $\mathrm{R}$ & PI88788 & 2.3 & 10 & 0.6 & 1.08 & 3,259 \\
\hline CX-260C & Dekalb & $\mathrm{R}$ & PI88788 & 2.6 & 5 & 0.4 & 0.96 & 2,578 \\
\hline EX1983 & Thompson & $\mathrm{R}$ & ND & ND & 3 & ND & 1.05 & 2,564 \\
\hline EX-342CN & Latham & $\mathrm{R}$ & ND & ND & 2 & ND & 0.99 & 3,218 \\
\hline EX717 & Dekalb & $\mathrm{R}$ & ND & ND & 2 & ND & 1.01 & 3,285 \\
\hline EX719 & Dekalb & $\mathrm{R}$ & ND & ND & 2 & ND & 1.03 & 3,335 \\
\hline Faribault & MN Agric. Exp. St. & $\mathrm{R}$ & PI209332 & 1.9 & 15 & 0.5 & 0.91 & 2,656 \\
\hline Freeborn & MN Agric. Exp. St. & $\mathrm{R}$ & PI88788 & 1.6 & 15 & 0.4 & 0.97 & 2,830 \\
\hline IA 2036 & IA Agric. Exp. St. & $\mathrm{R}$ & PI88788 & 2.1 & 10 & 0.5 & 1.02 & 3,064 \\
\hline J700CN & Jacobsen & $\mathrm{R}$ & ND & ND & 2 & ND & 1.08 & 3,484 \\
\hline J770CN & Jacobsen & $\mathrm{R}$ & ND & 2.0 & 4 & 0.7 & 1.01 & 2,576 \\
\hline $\mathrm{K}-2120 \mathrm{SCN}$ & Kruger & $\mathrm{R}$ & ND & 1.9 & 4 & 0.6 & 1.08 & 3,746 \\
\hline Newton & IA Agric. Exp. St. & $\mathrm{R}$ & Peking & 2.5 & 5 & ND & 0.76 & 2,116 \\
\hline PB-188N & Prairie & $\mathrm{R}$ & PI88788 & 1.8 & 8 & 1.7 & 1.03 & 3,103 \\
\hline PB-210N & Prairie & $\mathrm{R}$ & ND & ND & 2 & ND & 1.03 & 3,313 \\
\hline PB-215N & Prairie & $\mathrm{R}$ & PI88788 & 2.1 & 8 & 0.6 & 1.02 & 3,064 \\
\hline RS2297C & Renk & $\mathrm{R}$ & PI88788 & ND & 6 & 0.5 & 0.97 & 2,733 \\
\hline S18-11 & Novartis (Northrup King) & $\mathrm{R}$ & PI88788 & 1.8 & 13 & 0.5 & 1.02 & 2,923 \\
\hline SOI201N & Sands of Iowa & $\mathrm{R}$ & PI88788 & 2.0 & 4 & 0.7 & 1.08 & 2,761 \\
\hline X58212 & Mycogen & $\mathrm{R}$ & PI88788 & 2.1 & 4 & 0.7 & 0.99 & 2,518 \\
\hline 1901 & Asgrow & $\mathrm{S}$ & & 1.9 & 6 & 2.9 & 0.75 & 2,019 \\
\hline D163 N & ICI-Garst & $\mathrm{S}$ & PI88788 & 1.6 & 4 & 1.2 & 0.84 & 2,605 \\
\hline GL1559 & Great Lakes Seed & $\mathrm{S}$ & PI88788 & 1.5 & 4 & 3.3 & 0.80 & 2,035 \\
\hline IA $2008 \mathrm{R}$ & IA Agric. Exp. St. & $\mathrm{S}$ & & 2.2 & 5 & ND & 1.00 & 2,765 \\
\hline IA 2021 & IA Agric. Exp. St. & $\mathrm{S}$ & & 2.1 & 7 & 4.0 & 1.07 & 3,039 \\
\hline Macus 95 & IA Agric. Exp. St. & $\mathrm{S}$ & & ND & 5 & ND & 1.04 & 2,865 \\
\hline Parker & MN Agric. Exp. St. & $\mathrm{S}$ & & 1.5 & 15 & 4.5 & 0.85 & 2,496 \\
\hline Sturdy & MN Agric. Exp. St. & $\mathrm{S}$ & & 2.1 & 11 & 3.0 & 0.93 & 2,511 \\
\hline $3198 \mathrm{CN}$ & Thompson Seeds & $\mathrm{S}^{\mathrm{e}}$ & PI88788 & 1.9 & 3 & ND & 1.04 & 2,535 \\
\hline
\end{tabular}


ventional soybean herbicides were used to reduce weed pressure.

Data collection. For each plot at SCNinfested sites in every year, soil samples were collected in the spring immediately after planting and in the fall within 2 weeks prior to or within 2 weeks after harvest (Table 2). Each soil sample was a composite of 12 soil cores collected with a 2.5 -cm-diameter $($ tip diameter $=2.0 \mathrm{~cm}$ ) soil probe to a depth of $20 \mathrm{~cm}$ in the inner two rows of each plot. The soil was mixed thoroughly, and nematode egg density was determined from a $100 \mathrm{~cm}^{3}$ soil subsample. For the soil samples collected in the spring and fall of 1996 and in the spring of 1997 , SCN eggs were extracted with a handdecanting and sucrose flotation procedure. For the soil samples collected in the fall of 1997 and the spring and fall of 1998, cysts were extracted with a semiautomatic elutriator (3). Eggs were released from the cysts using a modified mechanical method (9) in 1996 or by breaking the cysts in a 40-ml glass tissue grinder (Fisher Scientific, Pittsburgh, PA) in 1997 and 1998. The eggs were suspended in $50 \mathrm{ml}$ of water. Number of eggs was counted in 0.5 to $5.0 \mathrm{ml}$ of the egg suspension, depending upon the numbers of eggs, and the total number of eggs in $100 \mathrm{~cm}^{3}$ soil was derived. For sites W96 and W97, the number of females that developed on soybean roots 40 days (1996) or 45 days (1997) after planting was determined. Twelve soybean plants were dug from the outer two rows in each plot. The root systems were soaked in water for at least $12 \mathrm{~h}$ before gently washing off adhering soil. SCN females were dislodged by washing vigorously with a water stream through an $800-\mu \mathrm{m}$-aperture sieve onto a $150-\mu \mathrm{m}$-aperture sieve, and females were separated from debris by centrifugation in $76 \%$ (wt/vol) sucrose solution. The total number of females from the 12 plants was counted and average number of females per plant root system was determined for each plot.

For each plot in every year, soybean seed yields were measured from $4 \mathrm{~m}$ of the two inner rows in 4.6-m-long plots and $3 \mathrm{~m}$ of the two inner rows in 3.7-m-long plots using a small plot combine. Yields were standardized to $13 \%$ moisture.

Data analysis. Analysis of variance (ANOVA) was used to evaluate variation in soybean yield and SCN density among replicates at each site. Contrast $(P=0.05)$ in yield and SCN density between the group of SCN-resistant cultivars and the group of susceptible cultivars at each site was determined.

Yield potential at different sites may have been different because of variation in soil fertility as well as other environmental and climatic factors. To standardize yield across sites, relative yield was computed for each cultivar by dividing the yield of a cultivar by the average yield of the resistant cultivars at a site. The average relative yield of an individual cultivar at all SCNinfested sites over 3 years also was computed. The relationship between average relative yield of susceptible cultivars at a site and initial SCN population density (Pi = egg density at planting) at the site was analyzed by regression with $Y=\mathrm{a} e^{\mathrm{b} x}$, where $Y$ is average relative yield, $x$ is initial egg density, a is the maximum yield, $e$ is the base of the natural logarithm, and b is the rate parameter (1).

At the eight sites where $\mathrm{Pi}$ was more than 1,000 eggs per $100 \mathrm{~cm}^{3}$ soil, the $\mathrm{SCN}$ reproduction factor ( $\mathrm{Rf}$ ) during the growing season was determined by dividing final $\mathrm{SCN}$ population density $(\mathrm{Pf}=\mathrm{egg}$ density at harvest) by Pi. Regression was used to quantify the relationship between yield of individual cultivars and SCN reproduction factor using the equation of $Y=$ $\mathrm{a} e^{\mathrm{b} x}$, where $Y$ is the soybean yield, and $x$ is Pf or Rf. The relationship between Rf and number of first-generation SCN females formed on soybean roots and the relationship between yield and the number of females on roots at the W96 and W97 sites were also analyzed by regression. Correlation analysis was performed to determine the effect of soil texture, $\mathrm{pH}$, organic matter (Table 2), and elements (data not shown) on SCN Rf and Pf.

To determine the yield benefit of resistant over susceptible cultivars in response to SCN density, linear regression was performed using the percent yield difference between resistant and susceptible cultivars at each site as the dependent variable and the $\mathrm{Pi}$ at the site as the independent variable. The percent yield difference $=$ (average yield of resistant cultivars - average yield of susceptible cultivar) $\times 100 /$ average yield of resistant cultivars.

To determine consistency of development of SCN populations in the cultivars among the different sites and years, the Pearson correlation coefficient of $\mathrm{Rf}$ on cultivars in each pair of sites was determined. For this analysis, only the eight sites where the Pi was above 1,000 eggs per $100 \mathrm{~cm}^{3}$ soil were included, because variability in $\mathrm{Rf}$ was large when $\mathrm{Pi}$ was low. Analyses of correlation in yields of individual cultivars between sites also were done to determine the consistency of yield response of the cultivars in the 17 sites over 3 years.

\section{RESULTS}

Soybean cyst nematode population development. No difference in $\mathrm{Pi}$ was observed among plots within a field at most sites $(P>0.05$, data not shown), but the Pi varied among sites (Table 3 ). Generally, there was greater variation in $\mathrm{Pi}$ among plots at a site with a lower SCN population density than at a site with a higher population density (data not shown). More SCN developed on susceptible culti-

Table 2. Site designation, planting dates, Heterodera glycines sampling dates, races, and soil characteristics

\begin{tabular}{|c|c|c|c|c|c|c|c|c|c|c|c|c|}
\hline \multirow[b]{3}{*}{ Year } & \multirow{3}{*}{$\begin{array}{c}\text { Site } \\
\text { designation }\end{array}$} & \multirow[b]{3}{*}{ Location } & \multirow[b]{3}{*}{ County } & \multirow{3}{*}{$\begin{array}{l}\text { Planting } \\
\text { date }\end{array}$} & & & \multirow{3}{*}{$\begin{array}{l}\mathrm{SCN} \\
\text { race }\end{array}$} & \multicolumn{5}{|c|}{ Soil characteristics } \\
\hline & & & & & \multicolumn{2}{|c|}{ SCN sampling date } & & \multirow{2}{*}{$\begin{array}{l}\text { Sand } \\
(\%)\end{array}$} & \multirow{2}{*}{$\begin{array}{l}\text { Silt } \\
(\%)\end{array}$} & \multirow{2}{*}{$\begin{array}{l}\text { Clay } \\
(\%)\end{array}$} & \multirow{2}{*}{$\begin{array}{l}\text { O.M. } \\
(\%)\end{array}$} & \multirow[b]{2}{*}{ pH } \\
\hline & & & & & Spring & Fall & & & & & & \\
\hline \multirow[t]{5}{*}{1996} & W96 & Waseca & Waseca & $5 / 23$ & $5 / 20$ & $10 / 15$ & 3 & 28.0 & 37.2 & 34.9 & 6.1 & 6.8 \\
\hline & L96 & Lamberton & Redwood & $5 / 21$ & $5 / 21$ & $11 / 5$ & 1 & 22.8 & 41.9 & 35.3 & 7.1 & 7.7 \\
\hline & EC96 & East Chain & Jackson & $6 / 4$ & $6 / 12$ & $10 / 8$ & 3 & 61.0 & 21.5 & 17.5 & 3.4 & 7.8 \\
\hline & SJ96 & St. James & Watonwan & $5 / 26$ & $6 / 11$ & $10 / 1$ & 3 & 78.9 & 11.7 & 9.4 & 2.5 & 7.9 \\
\hline & NR96 & New Richland & Waseca & $5 / 30$ & $6 / 13$ & $10 / 8$ & 3 & 37.4 & 32.4 & 30.2 & 7.3 & 7.8 \\
\hline \multirow[t]{4}{*}{1997} & W97I & Waseca & Waseca & $5 / 10$ & $5 / 15$ & $10 / 15$ & 3 & 21.8 & 45.9 & 32.3 & 9.9 & 7.8 \\
\hline & W97II & Waseca & Waseca & $5 / 19$ & $6 / 12$ & $10 / 17$ & 3 & 37.4 & 34.6 & 28.1 & 4.5 & 6.4 \\
\hline & SJ97 & St. James & Watonwan & $5 / 19$ & $6 / 11$ & $10 / 16$ & 3 & 78.9 & 11.7 & 9.4 & 2.5 & 7.9 \\
\hline & L97 & Lamberton & Redwood & $5 / 12$ & $5 / 14$ & $9 / 18$ & 1 & 22.8 & 41.9 & 35.3 & 7.1 & 7.7 \\
\hline \multirow[t]{8}{*}{1998} & W98I & Waseca & Waseca & $5 / 20$ & $5 / 21$ & $11 / 4$ & 3 & 9.3 & 43.8 & 46.9 & 7.5 & 7.7 \\
\hline & W98II & Waseca & Waseca & $5 / 20$ & $5 / 21$ & $10 / 26$ & 3 & 21.8 & 45.9 & 32.3 & 9.9 & 7.8 \\
\hline & L98I & Lamberton & Redwood & $5 / 14$ & $5 / 15$ & $10 / 21$ & 3 & 41.7 & 31.9 & 26.3 & 5.0 & 7.7 \\
\hline & SJ98 & St. James & Watonwan & $5 / 13$ & $6 / 8$ & $10 / 15$ & 3 & 51.4 & 23.5 & 25.1 & 5.8 & 7.9 \\
\hline & K98 & Kenyon & Goodhue & $5 / 14$ & $6 / 4$ & $\mathrm{ND}^{\mathrm{a}}$ & 3 & 7.2 & 67.8 & 25.0 & 5.6 & 7.3 \\
\hline & G98 & Geneva & Steele & $5 / 14$ & $6 / 4$ & ND & 3 & 58.0 & 22.3 & 19.6 & 7.0 & 7.7 \\
\hline & W98III & Waseca & Waseca & $5 / 14$ & ND & ND & $\mathrm{NN}$ & ND & ND & ND & ND & ND \\
\hline & L98II & Lamberton & Redwood & $5 / 14$ & ND & ND & $\mathrm{NN}^{\mathrm{b}}$ & ND & ND & ND & ND & ND \\
\hline
\end{tabular}

\footnotetext{
${ }^{a}$ No data.

b No soybean cyst nematodes.
} 
vars than on resistant cultivars at most sites. The reduction of SCN populations over the course of a growing season varied among resistant cultivars. Not all resistant cultivars reduced $\mathrm{SCN}$ population density in all sites; the average $\mathrm{Rf}$ on individual resistant cultivars in the sites infested with more than 1,000 eggs per $100 \mathrm{~cm}^{3}$ soil ranged from 0.3 to 1.7 (Table 1 ).

Females on roots. In 1996, average numbers of females that developed on resistant cultivars were 21 per plant compared with 57 on the susceptible cultivars at the W96 site. Five females per plant developed on Pioneer 9234, and nine females developed on Northrup King (now Novartis) S18-11 at Waseca (W96), the varieties with lowest counts. In contrast, the numbers of females that developed per plant on the susceptible cultivars Sturdy and Parker were 53 and 61, respectively. Other resistant cultivars supported 17 to 33 females per plant. In 1997, the average number of females on resistant cultivars was 20 per plant compared with 139 per plant on susceptible cultivars. The numbers of females that developed on 9234 and S18-11 at W97 were again the lowest among the tested resistant cultivars, at 1 and 8 females per plant, respectively, while 105 to 177 females developed per plant on the four susceptible cultivars. Among the cultivars, $\mathrm{Rf}$ was related positively with the number of females that developed on roots (Fig. 1), although the number of females on roots and $\mathrm{Rf}$ varied among sites and years.

Egg densities in 1996. Average Pi at the W96 site was 6,036 eggs per $100 \mathrm{~cm}^{3}$ soil. The average egg density reduction during the growing season was $71 \%$ [(average Pi on all resistant cultivars - average Pf) $\times$ 100/average Pi] on resistant cultivars, while no change in egg density was observed on susceptible cultivars (Table 3 ). Final egg densities on 9234 and S18-11 were only 9 and $16 \%$, respectively, of the Pi.

At the L96 site, the Pi averaged 5,146 eggs per $100 \mathrm{~cm}^{3}$ soil. The SCN egg density increased 4.6- and 10.6-fold on the
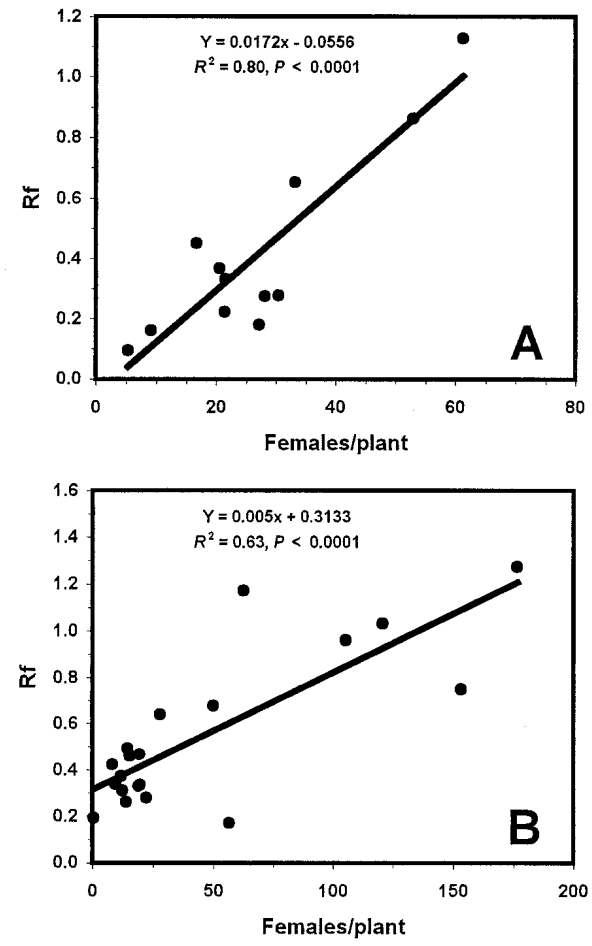

Fig. 1. Relationship between nematode reproduction factors (Rf) and number of Heterodera glycines females on soybean roots A, 40 days (1996) or B, 45 days (1997) after planting for resistant and susceptible cultivars at Waseca, MN.

Table 3. Average population development of Heterodera glycines and associated yield of resistant $(\mathrm{R})$ and susceptible (S) soybean cultivars in fields in southern Minnesota during 1996 to 1998

\begin{tabular}{|c|c|c|c|c|c|c|c|c|c|c|c|c|c|c|c|}
\hline \multirow[b]{3}{*}{ Year } & \multirow[b]{3}{*}{ Site } & \multirow{2}{*}{\multicolumn{2}{|c|}{$\begin{array}{c}\text { No. of } \\
\text { cultivars }\end{array}$}} & \multirow{2}{*}{\multicolumn{2}{|c|}{$\mathbf{P i}^{\mathbf{a}}$}} & \multicolumn{4}{|c|}{$\mathbf{P f}^{b}$} & \multirow{2}{*}{\multicolumn{2}{|c|}{$\begin{array}{c}\text { Comparison } \\
\text { between Pi and Pf }\end{array}$}} & \multicolumn{4}{|c|}{ Yield (kg/ha) } \\
\hline & & & & & & \multirow[b]{2}{*}{$\mathbf{R}$} & \multirow[b]{2}{*}{$\mathbf{S}$} & \multirow[b]{2}{*}{ ANOVAc } & \multirow{2}{*}{$\begin{array}{l}\text { Contrast } \\
\text { R vs. S }\end{array}$} & & & \multirow[b]{2}{*}{$\mathbf{R}$} & \multirow[b]{2}{*}{$\mathbf{S}$} & \multirow[b]{2}{*}{ ANOVAc $^{c}$} & \multirow{2}{*}{$\begin{array}{l}\text { Contrast } \\
\text { R vs. S }\end{array}$} \\
\hline & & $\mathbf{R}$ & $\overline{\mathbf{S}}$ & $\mathbf{R}$ & $\mathbf{S}$ & & & & & $\mathbf{R}$ & $\bar{S}$ & & & & \\
\hline \multirow[t]{5}{*}{1996} & W96 & 10 & 2 & 6,119 & 5,625 & 1,724 & 5,428 & $* * \mathrm{~d}$ & $* * *$ & $* * *$ & NS & 2,627 & 2,730 & $* * *$ & NS \\
\hline & L96 & 10 & 2 & 4,936 & 6,194 & 3,523 & 35,175 & $* * *$ & $* * *$ & $P=0.06$ & $*$ & 3,773 & 3,248 & $* * *$ & $* *$ \\
\hline & EC96 & 15 & 6 & 455 & 342 & 219 & 3,324 & $* * *$ & $* * *$ & NS & $* * *$ & 2,416 & 2,466 & $* *$ & NS \\
\hline & SJ96 & 15 & 6 & 412 & 490 & 271 & 5,208 & $* * *$ & $* * *$ & NS & $* * *$ & 2,476 & 2,365 & $* *$ & NS \\
\hline & NR96 & 15 & 6 & 63 & 2 & 95 & 704 & ** & $* * *$ & NS & $* *$ & 2,550 & 2,576 & $* * *$ & NS \\
\hline \multirow[t]{4}{*}{1997} & W97I & 16 & 4 & 7,517 & 7,454 & 2,708 & 8,163 & $* * *$ & $* * *$ & $* * *$ & NS & 2,928 & 2,549 & NS & $* *$ \\
\hline & W97II & 22 & 5 & 154 & 90 & 136 & 5,607 & $* * *$ & $* * *$ & $\mathrm{NS}^{\mathrm{e}}$ & $* * * \mathrm{e}$ & 3,056 & 3,013 & $* * *$ & NS \\
\hline & SJ97 & 22 & 5 & 805 & 525 & 378 & 5,146 & $* * *$ & $* * *$ & $* * *$ & $* * *$ & 3,445 & 3,244 & $P=0.07$ & * \\
\hline & L97 & 15 & 4 & 12,500 & 11,942 & 4,705 & 19,915 & $* *$ & $* * *$ & $* * *$ & NS & 3,080 & 2,402 & NS & $* *$ \\
\hline \multirow[t]{8}{*}{1998} & W98I & 32 & 4 & 1,935 & 1,713 & 1,198 & 10,747 & $* * *$ & $* * *$ & $* * *$ & $* * *$ & 2,372 & 1,900 & $* * *$ & $*$ \\
\hline & W98II & 28 & 2 & 928 & 2,003 & 2,632 & 35,117 & $* * *$ & $* * *$ & $* * * \mathrm{e}$ & $* * *$ & 3,915 & 3,888 & NS & NS \\
\hline & W98III & 32 & 4 & 0 & 0 & $N D^{f}$ & ND & & & & & 3,148 & 3,099 & *** & NS \\
\hline & L98I & 32 & 4 & 10,942 & 10,151 & 5,584 & 19,400 & $* * *$ & $* * *$ & $* * *$ & $*$ & 3,128 & 2,093 & $* * *$ & $* * *$ \\
\hline & L98II & 32 & 4 & 0 & 0 & ND & ND & & & & & 4,106 & 3,761 & $* * *$ & NS \\
\hline & SJ98 & 28 & 2 & 2,296 & 2,229 & 2,104 & 11,979 & $* * *$ & $* * *$ & NS & $* * *$ & 3,544 & 2,924 & $* *$ & $*$ \\
\hline & G98 & 32 & 4 & 9,937 & 8,486 & 6,519 & 32,828 & $* * *$ & $* * *$ & $* * *$ & $* * *$ & 2,383 & 1,618 & $*$ & $* * *$ \\
\hline & K98 & 32 & 4 & 261 & 314 & 282 & 2,740 & $* * *$ & $* * *$ & NS & $* *$ & 2,595 & 2,504 & $* * *$ & NS \\
\hline
\end{tabular}

a Nematode density at planting (eggs per $100 \mathrm{~cm}^{3}$ soil).

${ }^{b}$ Nematode density at harvest (eggs per $100 \mathrm{~cm}^{3}$ soil).

c Analysis of variance (ANOVA) was used to quantify variation among replicates and differences among all individual cultivars.

$\mathrm{d} *, * *$, and $* * *$ represent significant at $P=0.05, P=0.01$, and $P=0.001$, respectively. NS $=$ not significant.

e Effect of interaction between cultivar and sampling occasion on egg density was significant at $P=0.05$.

${ }^{\mathrm{f}} \mathrm{ND}=$ not determined. 
susceptible cultivars Sturdy and Parker, respectively. Egg density was reduced up to $82 \%$ by cultivar 9234 (data not shown) and by an average of $29 \%(P=0.06)$

At the NR96 site, average Pi was low (Table 3) and highly variable among plots. At the EC96 and SJ96 sites, the average Pi were 423 and 434 eggs per $100 \mathrm{~cm}^{3}$ soil, respectively, and average $\mathrm{Pf}$ on resistant cultivars were 52 and $34 \%$ of $\mathrm{Pi}$, respectively, with the differences between Pf and Pi not statistically significant. In contrast, susceptible cultivars increased an average egg density 9.7-fold and 10.6-fold at the EC96 and SJ96 sites, respectively (Table 3).

Egg densities in 1997. The average $\mathrm{Pi}$ at the W97I site was 7,460 eggs per $100 \mathrm{~cm}^{3}$ soil. The average egg density was reduced $64 \%$ by resistant cultivars, but no significant change in the SCN population density with susceptible cultivars was observed (Table 3). At the L97 site, Pi were higher than at other sites (Table 3). On average, resistant cultivars reduced egg densities from 12,500 to 4,705 eggs per $100 \mathrm{~cm}^{3}$ soil (62\% reduction), whereas there was no significant change in egg densities on susceptible cultivars (Table 3). Pioneer 9234 reduced nematode egg density by 81 and $84 \%$ at the W97I and L97 sites, respectively. At the W97II site, average Pi was 142 eggs per $100 \mathrm{~cm}^{3}$ soil, and average Pf was 136 and 5,607 eggs per $100 \mathrm{~cm}^{3}$ soil on the resistant and susceptible cultivars, respectively. However, interactions between cultivar and sampling dates were significant for resistant cultivars as well as for susceptible cultivars (Table 3), suggesting that $\mathrm{SCN}$ reproduced at differing rates on resistant cultivars as well as susceptible cultivars. At the SJ97 site, egg density decreased from 805 to 378 eggs per 100 $\mathrm{cm}^{3}$ soil on resistant cultivars and increased from 525 to 5,146 eggs per 100 $\mathrm{cm}^{3}$ soil on susceptible cultivars (Table 3 ).

Egg densities in 1998. At the W98I site, average egg density decreased from 1,935 to 1,198 eggs per $100 \mathrm{~cm}^{3}$ soil in plots in which resistant cultivars were grown and increased from 1,713 to 10,747 eggs per across all resistant cultivars (Table 3 ).

$100 \mathrm{~cm}^{3}$ soil in plots in which susceptible cultivars were grown (Table 3). At the L98I and G98 sites, SCN egg density on susceptible cultivars increased by 91 and $287 \%$, respectively, even at a high $\mathrm{Pi}$ $\left(10,151\right.$ and 8,486 eggs per $100 \mathrm{~cm}^{3}$ soil, respectively) (Table 3 ). In contrast, average egg density decreased on resistant cultivars by 49 and $34 \%$ at these two sites, respectively (Table 3). At the K98 site, egg density increased from 314 to 2,740 eggs per $100 \mathrm{~cm}^{3}$ soil in plots grown with susceptible cultivars, but there was no change in egg density in plots grown with resistant cultivars (Table 3 ).

At the W98II site, average Pi was 1,000 eggs per $100 \mathrm{~cm}^{3}$ soil, and the egg density increased to an average of 35,117 eggs per $100 \mathrm{~cm}^{3}$ soil in plots of susceptible cultivars at harvest. The Pf in resistant cultivars was 2,632 eggs per $100 \mathrm{~cm}^{3}$ soil, about three times the $\mathrm{Pi}$, and there was significant interaction between cultivar and sampling date on egg density (Table 3 ).

At the SJ98 site, egg density increased from a Pi of 2,296 eggs per $100 \mathrm{~cm}^{3}$ soil to 11,979 eggs per $100 \mathrm{~cm}^{3}$ soil at harvest in the plots grown with susceptible cultivars, whereas average Pf was similar to $\mathrm{Pi}$ on resistant cultivars (Table 3 ).

Correlation of $R f$ between sites. Correlation among reproduction factors for individual cultivars was observed for all 28 combinative pairs of the eight sites, with an average $r$ of 0.83 (0.67 to 0.99$)$, indicating consistency of $\mathrm{SCN}$ reproduction on the resistant and susceptible cultivars at the eight sites with the Pi more than 1,000 eggs per $100 \mathrm{~cm}^{3}$ soil. This correlation was not strong when Pi was low due to high variability among reproduction factors.

Effect of soil texture and fertility on SCN population. No significant correlation was observed between SCN Rf and soil texture, or between SCN Rf and soil fertility. Final egg density ( $\log _{10}$-transformed) correlated positively with organic matter $(r=0.6, P=$ $0.024)$ and $\mathrm{Ca}(r=0.67, P=0.009)$, but not soil texture, $\mathrm{pH}$, organic matter, $\mathrm{N}, \mathrm{P}$, $\mathrm{K}$, and $\mathrm{Mg}$.

Yield response. Resistant cultivars produced higher yields than did susceptible

Table 4. Relationship between yield of soybean cultivars and Pf or Rf of Heterodera glycines at sites infested with a high density of the nematode $\left(>1,000\right.$ eggs per $100 \mathrm{~cm}^{3}$ soil at planting)

\begin{tabular}{|c|c|c|c|c|c|}
\hline \multirow[b]{2}{*}{ Year } & \multirow[b]{2}{*}{ Site } & \multicolumn{2}{|c|}{ With Pf ${ }^{a}$} & \multicolumn{2}{|c|}{ With $\mathbf{R f}^{\mathbf{b}}$} \\
\hline & & $r^{\mathrm{c}}$ & $P^{\mathrm{d}}$ & $r$ & $P$ \\
\hline \multirow[t]{2}{*}{1996} & W96 & -0.02 & 0.940 & -0.07 & 0.824 \\
\hline & L96 & -0.60 & 0.037 & -0.55 & 0.078 \\
\hline \multirow[t]{2}{*}{1997} & W97I & -0.68 & 0.001 & -0.63 & 0.004 \\
\hline & L97 & -0.69 & 0.001 & -0.70 & 0.001 \\
\hline \multirow[t]{4}{*}{1998} & W98I & -0.46 & 0.004 & -0.49 & 0.002 \\
\hline & L98I & -0.57 & 0.000 & -0.67 & 0.000 \\
\hline & SJ98 & -0.56 & 0.001 & -0.47 & 0.009 \\
\hline & G98 & -0.67 & 0.000 & -0.63 & 0.000 \\
\hline
\end{tabular}

\footnotetext{
${ }^{a}$ Nematode density at harvest (eggs per $100 \mathrm{~cm}^{3}$ soil).

${ }^{\mathrm{b}}$ Egg density at harvest/egg density at planting.

${ }^{c}$ Pearson correlation coefficient.

d Significance level.
}

cultivars at eight of $10 \mathrm{SCN}$-infested sites where Pi were greater than 700 eggs per $100 \mathrm{~cm}^{3}$ soil (Table 3). Resistant cultivars produced an average of $3,082 \mathrm{~kg} / \mathrm{ha}$ compared with $2,497 \mathrm{~kg} / \mathrm{ha}$ by susceptible cultivars across the eight sites over 3 years. In fields infested with more than 5,000 eggs per $100 \mathrm{~cm}^{3}$ soil at planting, yield of resistant cultivars was $28.4 \%$ (676 kg/ha) more than the yield of susceptible cultivars. However, yield potential varied among the resistant cultivars, with an average relative yield of individual resistant cultivars across all SCN-infested sites ranging from 0.76 to 1.10 (Table 1).

In 1996, differences in yield among individual cultivars were observed at all five sites (Table 3). However, the contrast for yield between resistant cultivars and susceptible cultivars was significant $(P<$ 0.05 ) only at the L96 site, where resistant cultivars yielded $3,773 \mathrm{~kg} / \mathrm{ha}$ compared with susceptible cultivars yielding 3,248 $\mathrm{kg} / \mathrm{ha}$ (Table 3). There was no yield increase for resistant over susceptible cultivars at the W96 site even though the site was infested with an average $\mathrm{Pi}$ of 6,036 eggs per $100 \mathrm{~cm}^{3}$ soil.

In 1997, differences in yield among individual cultivars were observed only at the W97II site. Contrast of yields between resistant and susceptible cultivars was significant $(P<0.05)$ at the SJ97, W97I, and L97 sites (Table 3).

In 1998, differences in yield among individual cultivars were observed at all sites except at the W98II site (Table 3). In general, the contrast of yield between resistant and susceptible cultivars was significant $(P$ $<0.05$ ) when Pi were high (W98I, L98I, G98, and SJ98), but not when Pi were lower (K98 and W98II) or when SCN was not detected (W98III and L98II) (Table 3).

Relationship between yield and SCN density. Among all cultivars, yield was related negatively with both $\mathrm{Pf}$ and $\mathrm{Rf}$ at the eight sites with $\mathrm{Pi}$ of more than 1,000 eggs per $100 \mathrm{~cm}^{3}$ soil, except at the W96 site (Table 4). Average relative yield of individual cultivars for these sites was negatively related to reproductive factor (Fig. 2A). At the W97I site, yield decreased with increasing number of females that developed on soybean roots 45 days after planting (Fig. 2B).

The average relative yield of susceptible cultivars at each site was related negatively with Pi (Fig. 2C). However, variation in response of yield to Pi existed among sites. For example, difference in yield between resistant and susceptible cultivars was observed at the SJ97 site, where Pi was only 753 eggs per $100 \mathrm{~cm}^{3}$ soil, but not in the W98II site, where Pi was 1,000 eggs per $100 \mathrm{~cm}^{3}$ soil (Table 3). The relationship between the yield benefit of resistant over susceptible cultivars and Pi was described by a linear model, which demonstrated that the difference in yield between susceptible and resistant cultivars at a site 
increased with increasing Pi (Fig. 2D). Susceptible cultivars produced an average of $26 \%$ less yield than resistant cultivars if grown in fields infested with 10,000 eggs per $100 \mathrm{~cm}^{3}$ soil.

Yield consistency among sites. The correlation in yield of soybean individual cultivars between sites was not significant in most pairs of sites (96 out of 136 pairs). In the other 40 pairs of sites, the correlation was significant but the Pearson correlation coefficients were still low to moderate, indicating poor yield consistency in the relative ranking of cultivars among the sites.

\section{DISCUSSION}

In this study, we demonstrated that growing resistant cultivars in SCN-infested fields can prevent yield loss; however, yield potential varied among resistant cultivars. The average relative yield of individual cultivars across all SCN-infested sites ranged from 0.76 to 1.10 . The yield potential of a resistant cultivar depends on a number of factors such as agronomic characteristics and resistance to other diseases and insects; the physical, chemical, and biological factors of soil; weather conditions; and cultural practices. The poor consistency of relative ranking in yield response among sites suggests that these factors can significantly affect yields in the field.

The resistance depends on genetic interaction between soybean cultivars and SCN populations, and the effectiveness in use of resistant cultivars for SCN management is affected by genetic variation of SCN populations $(6,15)$. SCN populations at all sites except L96 and L97 were race 3. Although the populations at sites L96 and L97 were classified as race 1 according to the 16race scheme (13), the reproduction potential of the two populations on the differential soybean line PI 88788 was low (female index $=15 \%$ ) and thus was similar to race 3. Most SCN populations collected from southern Minnesota are classified as race 3 and have similar reproduction potentials on Peking and PI 88788, the source of SCNresistance for the cultivars used in this study (S. Y. Chen, unpublished). The genetic similarity of SCN populations among sites may explain the high consistency of reproductive factor at the eight sites. Since SCN populations were genetically similar among sites, inconsistency of yield of resistant cultivars even with similar SCN densities might be due to factors other than variation of SCN genetic composition at the sites.

The $\mathrm{Rf}$ represents the net rate of population change, including the fertility and mortality of SCN over the growing seasons. None of these resistant cultivars were immune to $\mathrm{SCN}$, and there was reproduction of SCN even on the highly resistant cultivars such as 9234, since eggs were observed from females formed on the re- sistant soybeans. There was greater reduction of SCN population on the highly resistant cultivars (e.g., 70\% on cv. 9234; Table 1) as compared with nonhost corn $(46 \%$ population reduction) over the growing seasons under comparable conditions (S. Y. Chen, unpublished). This result indicates that the mortality of SCN in fields grown
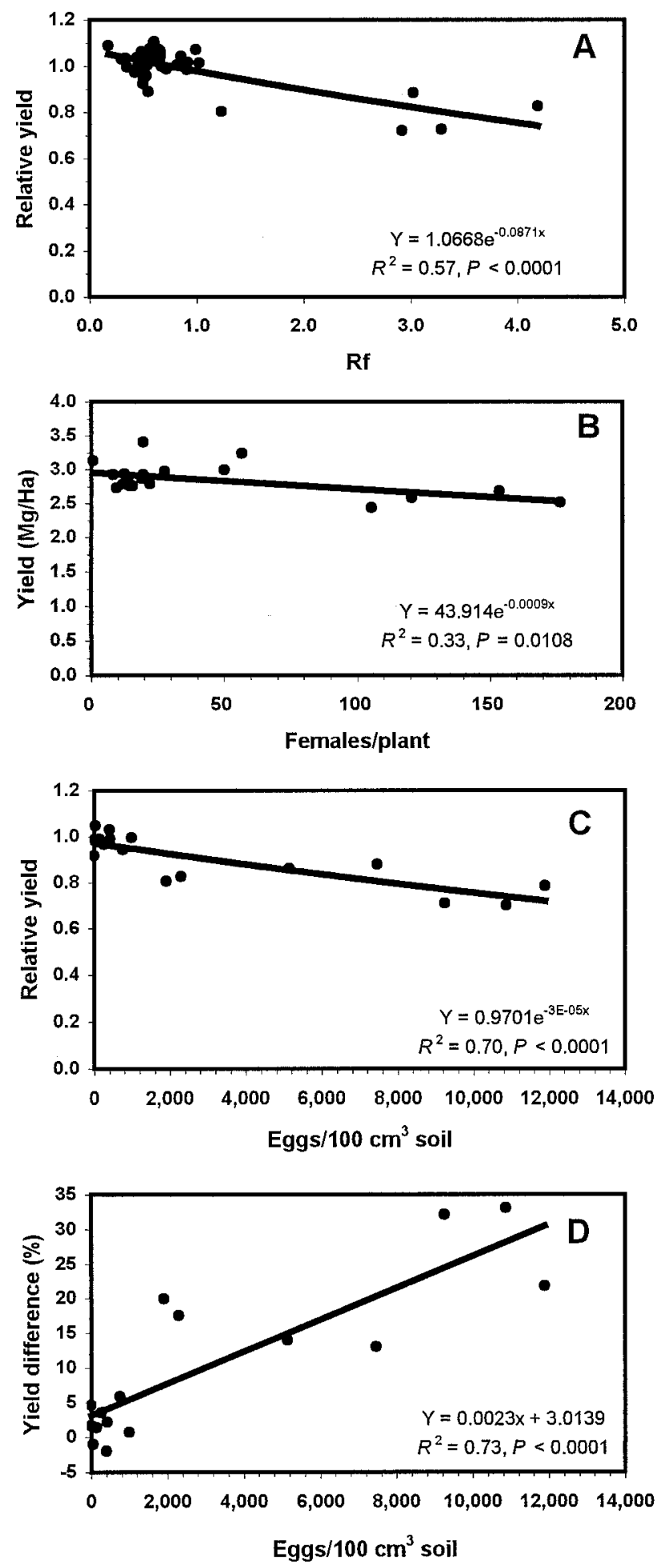

Fig. 2. Relationships among soybean yield and soybean cyst nematode (SCN) reproduction factors (Rf) and population densities. A, Relationship between average relative yield (yield of a cultivar/average yield of resistant cultivars at that site) and average Rf; each data point is a mean of a cultivar at all sites in southern Minnesota during 1996 to 1998. B, Relationship between yield of a cultivar and number of SCN females formed on soybean roots 45 days after planting at Waseca in 1998. C, Relationship between average relative yield of susceptible cultivars and average Pi during 1996 to 1998; each data point is a mean of all susceptible cultivars at one site. D, Relationship between yield benefit of planting resistant cultivars over susceptible cultivars and average Pi during 1996 to 1998; yield difference $=$ (average yield of resistant cultivars - average yield of susceptible cultivars) $\times 100 /$ average yield of resistant cultivars at a site. 
with highly resistant cultivars might be greater than with nonhost crops, possibly due to induced SCN hatch and limited support of SCN reproduction. However, resistant cultivars with a higher Rf (Table 1) appeared to result in greater Pf compared with the nonhost crop corn. This phenomenon was also observed in a previous report in which the resistant cultivars Bedford and Forrest resulted in greater SCN population density than expected for a nonhost crop (6).

Options for growing SCN-resistant soybeans with resistance sources other than PI 88788 currently are limited for the northern Corn Belt. Of the 47 SCN-resistant cultivars evaluated, only four had a source of resistance other than PI 88788. The cultivar Faribault has resistance from PI 209332; however, this cultivar had low relative yield. Three cultivars that carry resistance from the Peking source were 9234, Thompson Seed 3171, and Thompson Seed 3216 CN. Thompson Seed 3171 has a 1.7 maturity rating, but in 1998, it had a slightly low relative yield (0.97). Both 9234 and Thompson Seed 3216 have above average yield but a 2.2 maturity rating. Early MGII cultivars are considered full season for southern Minnesota and are not generally grown in the northern part of the state. If a rotation of SCN resistance sources is needed to slow race shifts $(6,22)$, additional early cultivars are needed with resistance sources other than PI 88788.

In this study, yields of susceptible cultivars were compared with yields of resistant cultivars. Yield loss for resistant cultivars caused by SCN could not be determined in this study, as has been reported from Missouri (5), Wisconsin (8), and Iowa (18). Further study is needed to determine the effect of SCN on yield of resistant soy- beans and to make a better estimation of yield loss for the susceptible cultivars in Minnesota fields.

\section{ACKNOWLEDGMENTS}

We thank J. Ballman, T. Ballman, R. Jaycox, J. Jin, S. Langager, J. Prechel, E. Senst, J. Shoenfield, J. Walgenbach, and L. Zielinski for technical assistance. We thank R. F. Nyvall, L. L. Kinkel, and D. A. Samac for valuable reviews.

\section{LITERATURE CITED}

1. Appel, J. A., and Lewis, S. A. 1984. Pathogenicity and reproduction of Hoplolaimus columbus and Meloidogyne incognita on 'Davis' soybean. J. Nematol. 16:349-355

2. Bradley, E. B., and Duffy, M. 1982. The value of plant resistance to soybean cyst nematodes; a case study of Forrest soybeans. U.S. Dep. Agric. Econ. Res. Serv. Nat. Res. Econ. Div.

3. Byrd, D. W., Jr., Barker, K. R., Ferris, H., Nusbaum, C. J., Griffin, W. E., Small, R. J., and Stone, C. A. 1976. Two semiautomatic elutriators for extracting nematodes and certain fungi from soil. J. Nematol. 8:206-212.

4. Chen, S. Y., Stienstra, W. C., Lueschen, W. E., and Hoverstad, T. R. 2001. Response of Heterodera glycines and soybean cultivar to tillage and row spacing. Plant Dis. 85:311-316.

5. Francl, L. J., and Dropkin, V. H. 1986. Heterodera glycines population dynamics and relation of initial population to soybean yield. Plant Dis. 70:791-795.

6. Francl, L. J., and Wrather, J. A. 1987. Effect of rotating 'Forrest' and 'Bedford' soybean on yield and soybean cyst nematode population dynamics. Crop Sci. 27:565-568.

7. MacDonald, D. H., Noel, G. R., and Lueschen, W. E. 1980. Soybean cyst nematode, Heterodera glycines, in Minnesota. Plant Dis. 64:319-321.

8. MacGuidwin, A. E., Grau, C. R., and Oplinger, E. S. 1995. Impact of planting 'Bell', a soybean cultivar resistant to Heterodera glycines, in Wisconsin. J. Nematol. 27:78-85.

9. Niblack, T. L., Heinz, R. D., Smith, G. S., and Donald, P. A. 1993. Distribution, density, and diversity of Heterodera glycines in Missouri. J. Nematol. 25:880-886.

10. Noel, G. R. 1987. Comparison of 'Fayette' soybean, aldicarb, and experimental nemati- cides for management of Heterodera glycines on soybean. Ann. Appl. Nematol. 1:84-88.

11. Noel, G. R. 1992. History, distribution, and economics. Page 1-13 in: Biology and Management of the Soybean Cyst Nematode. R. D. Riggs and J. A. Wrather, eds. American Phytopathological Society, St. Paul, MN.

12. Noel, G. R., and Sikora, E. J. 1990. Evaluation of soybeans in maturity groups I-IV for resistance to Heterodera glycines. J. Nematol. 22:795-799.

13. Riggs, R. D., and Schmitt, D. P. 1988. Complete characterization of the race scheme for Heterodera glycines. J. Nematol. 20:392-395.

14. Riggs, R. D., and Schmitt, D. P. 1991. Optimization of the Heterodera glycines race test procedure. J. Nematol. 23:149-154.

15. Schmitt, D. P. 1991. Management of Heterod era glycines by cropping and cultural practices. J. Nematol. 23:348-352.

16. Smith, G. S., Niblack, T. L., and Minor, H. C. 1991. Response of soybean cultivars to aldicarb in Heterodera glycines-infested soils in Missouri. J. Nematol. 23:693-698.

17. Smolik, J. D., Jones, J. L., Gallenberg, D. L., and Gille, J. P. 1996. First report of Heterodera glycines on soybean in South Dakota. Plant Dis. 80:224.

18. Tylka, G. L. 1997. Yield losses of Heterodera glycines-resistant soybean cultivars in Iowa in 1996. (Abstr.) J. Nematol. 29:610.

19. Wheeler, T. A., Pierson, P. E., Young, C. E., Riedel, R. M., Willson, H. R., Eisley, J. B., Schmitthenner, A. F., and Lipps, P. E. 1997. Effect of soybean cyst nematode (Heterodera glycines) on yield of resistant and susceptible soybean cultivars. J. Nematol. 29:703-709.

20. Wrather, J. A., Anderson, T. R., Arsyad, D. M., Gai, J., Ploper, L. D., Porta-Puglia, A., Ram, H. H., and Yorinori, J. T. 1997. Soybean disease loss estimates for the top 10 soybean producing countries in 1994. Plant Dis. 81:107-110.

21. Wrather, J. A., and Stienstra, W. C. 1999 Soybean disease loss estimates for the United States in 1996-1997. (Abstr.) Page 1 in: Natl. Soybean Cyst Nematode Conf. Proc.

22. Young, L. D. 1994. Changes in the Heterodera glycines female index as affected by tenyear cropping sequences. J. Nematol. 26:505510. 